Article

\title{
Studies on the Antibacterial Influence of Two Ionic Liquids and their Corrosion Inhibition Performance
}

\author{
Mohamed F. Shehata ${ }^{1}$, Ashraf M. El-Shamy ${ }^{1}$, Khaled M. Zohdy ${ }^{2}$, El-Sayed M. Sherif ${ }^{1,3}(\mathbb{D}$ and \\ Sherif Zein El Abedin 1 ** \\ 1 Physical Chemistry Department, Electrochemistry and Corrosion Lab., National Research Centre, \\ El-Bohouth St. 33, Dokki 12622, Giza, Egypt; mohamedfarouk3443@gmail.com (M.F.S.); \\ elshamy.ashraf@gmail.com (A.M.E.-S.); esherif@ksu.edu.sa (E.-S.M.S.) \\ 2 Higher Technological Institute, 10th of Ramadan City 44629, Egypt; drkhaledzohdy@hti.edu.eg \\ 3 Center of Excellence for Research in Engineering Materials, King Saud University, P.O. Box 800, \\ Al-Riyadh 11421, Saudi Arabia \\ * Correspondence: sherifzein888@gmail.com
}

Received: 20 December 2019; Accepted: 14 February 2020; Published: 20 February 2020

check for updates

Featured Application: We show in this paper that the ionic liquids [OH-EMIm]Cl and [EMIm]Cl can dually function as efficient biocides and corrosion inhibitors.

\begin{abstract}
In this paper the anti-bacterial and the anti-corrosion effect of two different ionic liquids, namely 1-(2-hydroxyethyl)-3-methylimidazolinium chloride ([OH-EMIm] $\mathrm{Cl}$ ) and 1-ethyl-3 -methyleimidazolinium chloride $([\mathrm{EMIm}] \mathrm{Cl})$ was demonstrated. The results revealed that the corrosion inhibition influence of the ionic liquid [OH-EMIm] $\mathrm{Cl}$ is higher than that of the ionic liquid [EMIm]Cl. Furthermore, the ionic liquid [OH-EMIm] Cl showed better biocidal influence compared with the ionic liquid [EMIm]Cl. This indicates the synergistic effect due to the incorporation of the hydroxyl group into the side chain of the imidazolium cation leading to enhanced antibacterial and anticorrosion effect.
\end{abstract}

Keywords: ionic liquids; corrosion; inhibition; microbial corrosion; biocide

\section{Introduction}

The corrosion is the main problem in cooling water systems. The corrosion may be metallic corrosion owing to the existence of water and/or microbial corrosion due to formation of bacterial biofilms [1]. The biofilm is regarded as a microbial community of embedded cells in a matrix of biopolymers called extracellular polymeric substances (EPS) formed on metallic and nonmetallic surfaces [2-4]. The favorable environmental conditions for formation of biofilms high doses of chloride ions and humidity [5]. The biofilms, which are responsible for the corrosion in cooling systems, are comprised of aerobic and anaerobic bacteria [6]. Due to its cost-effectiveness, the mild steel is considered as an important construction material in industry. The mild steel has low corrosion resistance compared with other metallic materials [7]. Hence, extensive work has been performed to mitigate the corrosion and microbial corrosion of mild steel using corrosion inhibitors and biocides, respectively [8]. There are many approaches for controlling the microbial corrosion including chemical, electrochemical, mechanical, and biological $[9,10]$. The prevention of the formation of biofilms is dependent on destroying the microbial community, which can be achieved by controlling the environmental conditions such as $\mathrm{pH}$, injected chemicals, and temperature [11].

A variety of chemicals such as, e.g., organic and inorganic compounds, natural products, or ionic liquids, were employed as both biocides and corrosion inhibitors [12-16]. Ionic liquids were introduced 
as efficient biocides and corrosion inhibitors for many metals and alloys in different media [17-20]. Zein El Abedin et al. [17] showed the potential of the ionic liquid 1-butyl-1-methylpyrrolidinium trifluoromethylsulfonate as a dual function inhibitor for the bacterial growth and for the corrosion of steel in $3.5 \% \mathrm{NaCl}$ solutionson the bacterial growth inhibition and on the corrosion inhibition of mild steel in $3.5 \% \mathrm{NaCl}$ solutions. The antimicrobial impact of hydroxyl-imidazolium chloride ionic liquids was reported [20].

In general, ionic liquids are comprised of large organic cations like, e.g., imidazolium, pyridinium, pyrrolidinium, phosphonium, and organic or inorganic anions such as, e.g., halide, nitrate, sulfate, trifluoromethylsulfonate, bis(trifluoromethylsulfonyl) amide, and dicyanamide. The large structure of ionic liquids and the existence of heteroatoms such as $\mathrm{N}, \mathrm{S}, \mathrm{O}$, or $\mathrm{P}$, and the bulky structure of ionic liquids make them potential candidates as potential corrosion inhibitors.

In this paper, two ionic liquids namely, 1-(2-hydroxyethyl)-3-methylimidazolinium chloride ([OH-EMIm]Cl) and 1-ethyl-3-methyleimidazolinium chloride ([EMIm] $\mathrm{Cl})$ were evaluated as biocides to reduce the microbial growth and to control the formation of biofilms.Bacterial contamination can cause biofouling and corrosion to many infrastructures and industrial units such as, e.g., cooling water systems, underground storage tanks, and water distribution systems [21-25]. The influence of the employed ionic liquids on the growth of planktonic bacteria was investigated.Furthermore, the inhibition efficiency of the employed ionic liquids on the corrosion of mild steel in chloride solutions was demonstrated. Incorporation of hydroxyl group into the side chain of the imidazolium cation of the ionic liquids can influence the biocidal activity as well as the corrosion inhibition efficiency of the ionic liquid.

\section{Materials and Methods}

\subsection{Materials}

Two ionic liquids namely, 1-(2-hydroxyethyl)-3-methylimidazolinium chloride ([OH-EMIm]Cl) and 1-ethyl-3-methyleimidazolinium chloride $([\mathrm{EMIm}] \mathrm{Cl})$ were employed. The ionic liquids were purchased from Io. Li. Tec., Germany, with a purity of $99 \%$ and were used as obtained without further purification. The chemical structures of the employed ionic liquids are shown Scheme 1.

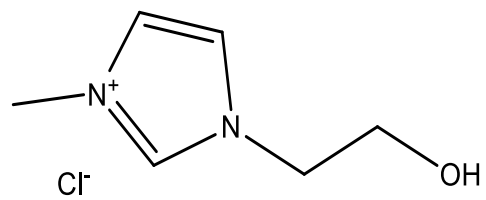

1-(2-hydroxyethyl)-3-methylimidazolium chloride

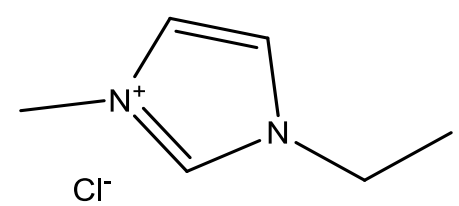

1-ethyl-3-methylimidazolium chloride

Scheme 1. Chemical structure of the employed ionic liquids.

Mild steel sheets were employed as working electrodes with dimensions of $1 \mathrm{~cm} \times 3 \mathrm{~cm} \times 0.1$ $\mathrm{cm}$. The employed mild steel electrodes have a chemical composition ( $w \mathrm{t} \%$ ) of $\mathrm{C}=1.92, \mathrm{Mn}=0.60$, $\mathrm{P}=0.17, \mathrm{Si}=0.15$, and restis Fe. The corrosion behavior of mild steel electrodes was investigated in $3.5 \% \mathrm{NaCl}$ solutions. Before immersing the mild steel coupon in the employed solutions, it was mechanically polished by emery papers of different grades to obtain a clean and smooth surface.

\subsection{Methods}

\subsubsection{Enumeration of Bacteria}

The most probable number (MPN) method was utilized for enumeration of bacteria. To enrich the planktonic bacterial growth, the water sample was subjected to circulation in open air for $24 \mathrm{~h}$, and then $1 \mathrm{~mL}$ was utilized to estimate the bacterial counts. Synthetic postgate media were distributed in test 
tubes, each tube contained $9 \mathrm{~mL}$. The circulated water was utilized to estimate the biocidal efficiency of the employed ionic liquids through injection of different doses of the employed ionic liquids.

\subsubsection{Electrochemical Measurements}

The potentiodynamic polarization studies

A Radiometer Voltalab master (Model PGZ 301) was used for the potentiodynamic polarization experiments. The potential was swept at a scan rate of $1 \mathrm{mVs}^{-1}$ and the respective current was recorded. The inhibition efficiency was determined using the Tafel extrapolation method, by using this formula:

$$
I E \%=\frac{i_{\text {corr }}-i^{\prime} \text { corr }}{i_{\text {corr }}} \times 100
$$

where, $i_{\text {corr }}$ and $i_{\text {corr }}$ are the corrosion current density in absence and in the presence of ionic liquid.

\section{Results and Discussion}

\subsection{Antibacterial Effect of the Employed Ionic Liquids}

The bacterial growth as a function of time in absence of the employed ionic liquids is shown in Figure 1. It is clearly seen, that the bacterial counts increase with time reaching a value of $10^{6}$ after $24 \mathrm{~h}$. Then different doses of ionic liquids were injected to investigate the influence of the employed ionic liquids on the inhibition of the growth of the planktonic bacteria.

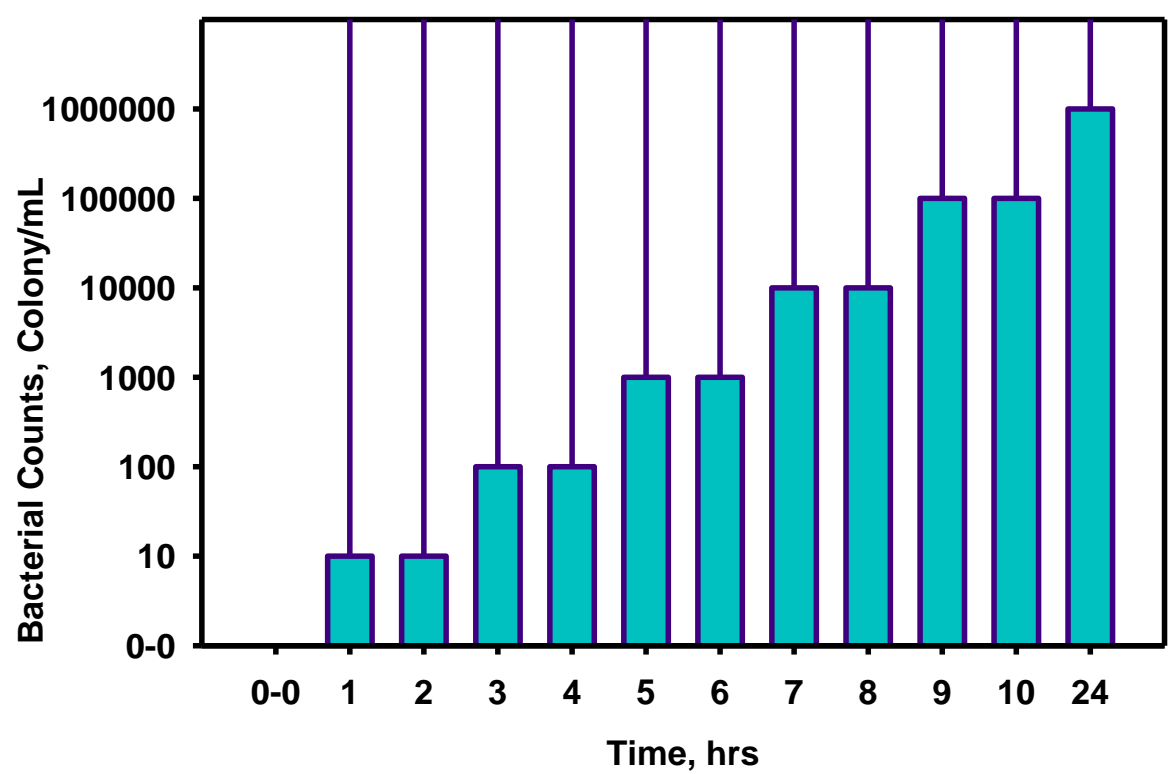

Figure 1. The counts of aerobic bacteria in the absence of ionic liquids.

The effect of the ionic liquids [OH-EMIm] $\mathrm{Cl}$ and $[\mathrm{EMIm}] \mathrm{Cl}$ on the growth of planktonic bacteria was investigated. Figure 2 shows the decay of bacterial counts by increasing the time at different concentrations of the ionic liquid [OH-EMIm]Cl. As shown in Figure 2, at a concentration of $25 \mathrm{ppm}$ the bacterial counts are linearly decreased by time and a complete inhibition of the bacterial growth is achieved after $6 \mathrm{~h}$ of injection. By increasing the concentration of the ionic liquid, the degree of bacterial growth inhibition rises and the highest effect was achieved at a concentration of $100 \mathrm{ppm}$. After 1 hour of injection, only 100 colony/mL was estimated at a concentration of $100 \mathrm{ppm}$ and a complete inhibition was reached after $3 \mathrm{~h}$. The change in the inhibition efficiency of the bacterial growth in the presence 
of different concentration of [OH-EMIm] $\mathrm{Cl}$ is presented in Figure 3. The inhibition efficiency of the injected ionic liquids was determined using the following equation:

$$
I E(\%)=\frac{\text { Bacterial }_{c}-\text { Bacterial }_{c(\text { inh })}}{\text { Bacterial }_{c}} \times 100
$$

where Bacterial $_{c}$ and Bacterial $_{(i n h)}$ are the bacterial counts in absence and in the presence of the ionic liquid, respectively.

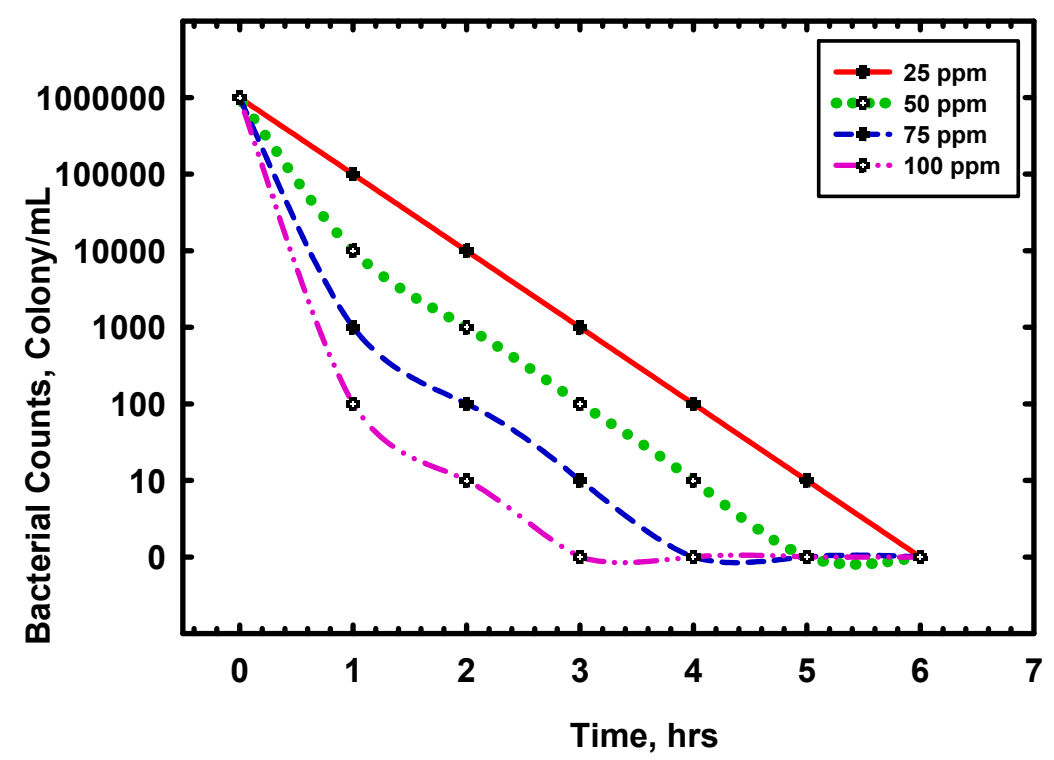

Figure 2. The decay of bacterial counts with time at different concentrations of the ionic liquid $[\mathrm{OH}-\mathrm{EMIm}] \mathrm{Cl}$.

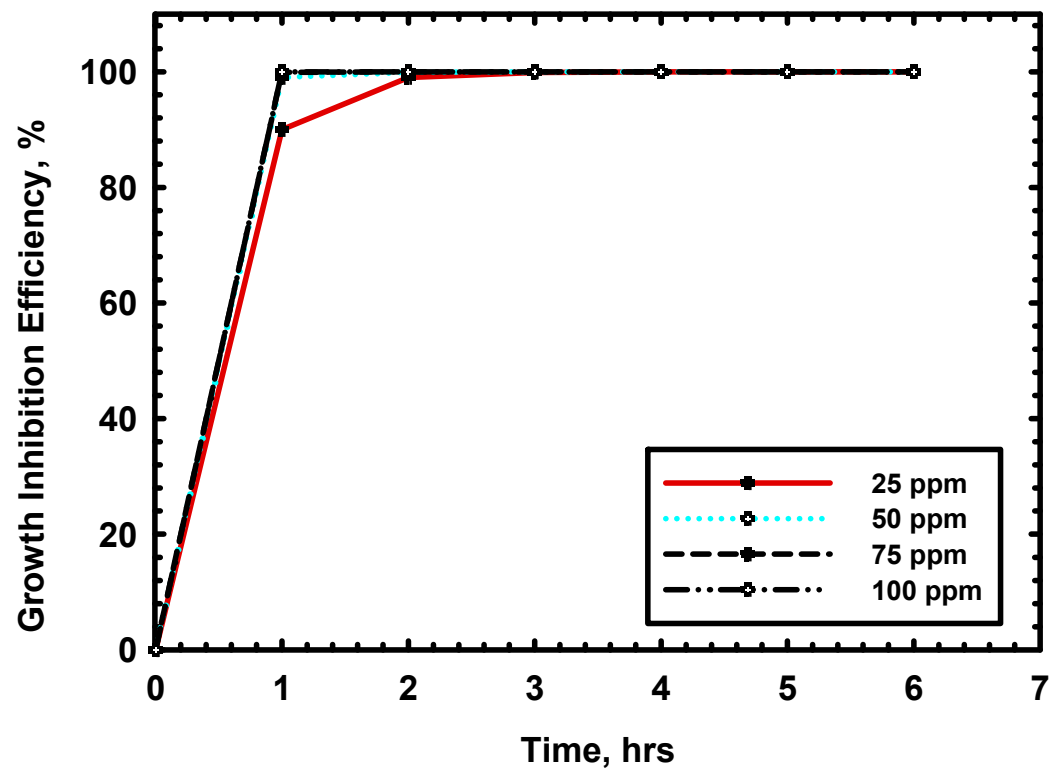

Figure 3. The inhibition efficiency of the bacterial growth in presence of different concentrations of [OH-EMIm]Cl.

As shown in Figure 3, the inhibition efficiency of the bacterial growth increased as the concentration of the ionic liquid increased. At a concentration of $25 \mathrm{ppm}$ of [OH-EMIm] Clthe inhibition efficiency of the bacterial growth reached $90 \%$ in one hour and about $99.9 \%$ was attained after three hours. 
However, at a concentration of $100 \mathrm{ppm}$ an inhibition efficiency of about $99.99 \%$ was obtained in one hour. These results indicate the bactericidal effect of ionic liquid [OH-EMIm] $\mathrm{Cl}$ and the inhibition efficiency were dependenton the ionic liquid concentration. In general, the antibacterial influence of the ionic liquids is attributed to the attraction of the ionic liquid species to the cell membrane causing its disruption [26].

Figure 4 shows the influence of the ionic liquid [EMIm] $\mathrm{Cl}$ on the planktonic bacterial growth. As in the case of [OH-EMIm]Cl, the presence of [EMIm] $\mathrm{Cl}$ led to a significant decrease in the bacterial counts with rates dependent on the concentration. However, higher concentrations of [EMIm] $\mathrm{Cl}$ are needed compared with those of [OH-EMIm] Cl to achieve comparable inhibition of the bacterial growth. Furthermore, a complete inhibition was not achieved with the duration of the investigation, up to $6 \mathrm{~h}$, in the case of [EMIm]Cl. As shown in Figure 4, a step-like behavior was observed as the ionic liquid concentration increased. This was attributable to the relatively lower rate of the bacterial growth inhibition of the ionic liquid [EMIm] $\mathrm{Cl}$ compared to that of the ionic liquid [OH-EMIm]Cl.

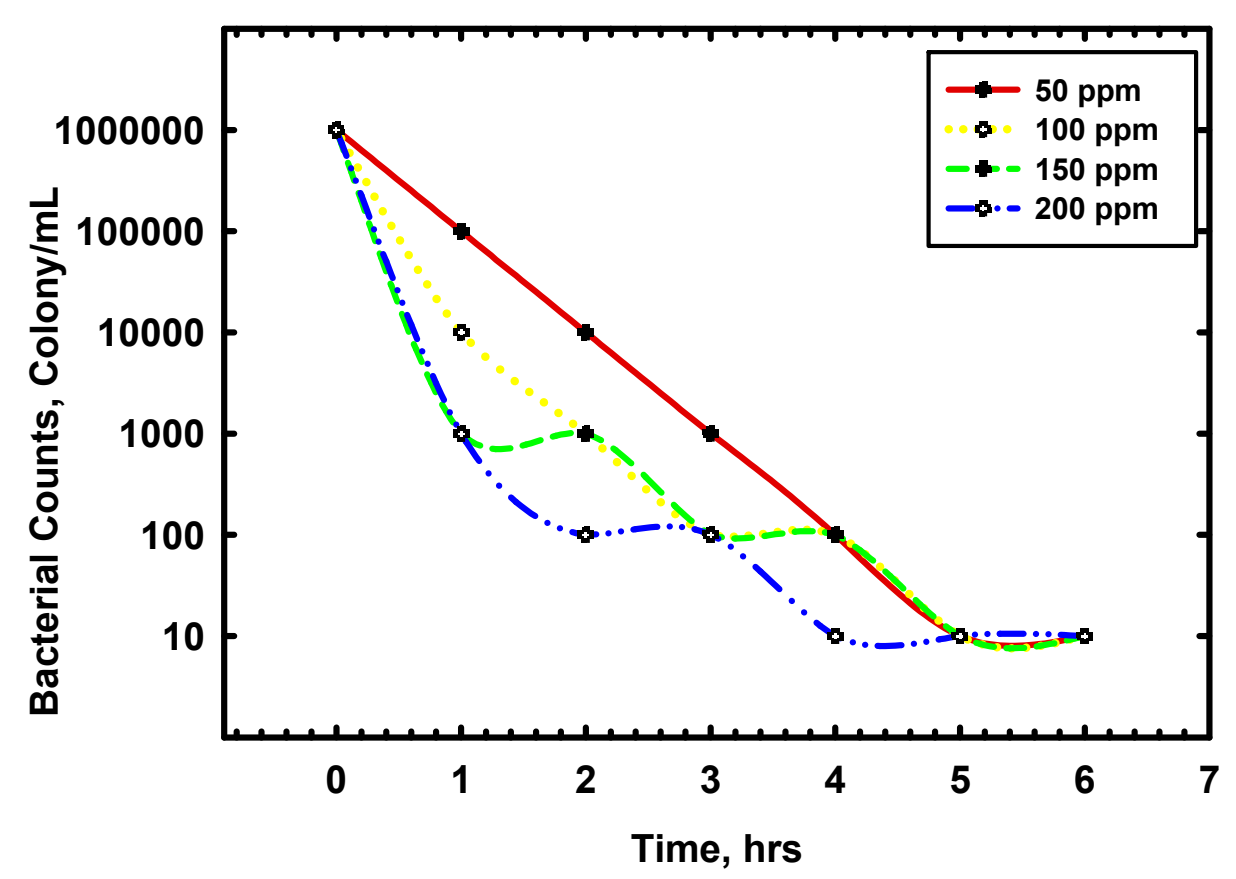

Figure 4. The decay of bacterial counts with time at different concentrations of the ionic liquid [EMIm]Cl.

The inhibition efficiency of the bacterial growth in the presence of different concentrations of [EMIm] $\mathrm{Cl}$ as a function of time is displayed in Figure 5. In the presence of ionic liquid concentrations above $50 \mathrm{ppm}$, an inhibition efficiency close to $99.9 \%$ was obtained in one hour. At one and the same concentration, the inhibition efficiency of [OH-EMIm] Clwas significantly higher than that of [EMIm]Cl. This can be attributed to the presence of hydroxyl group in the side chain of the imidazolium cation, which enhances the biocidal activity of the ionic liquid [OH-EMIm]Cl.

In light of the above results, it could be concluded thatin principle, the employed ionic liquids could effectively be utilized as efficient biocides to mitigate the bacterial growth, which, in turn, led to control of the microbially induced corrosion. As known, the bacterial colonization on a metal surface can enhance the formation of biofilms. This can cause local gradients of dissolved oxygen, $\mathrm{pH}$, and corrosive anions, which, in turn, lead to corrosion acceleration [27]. Thus, inhibition of the bacterial growth rate is requisite to mitigate the microbiallyinduced corrosion. 


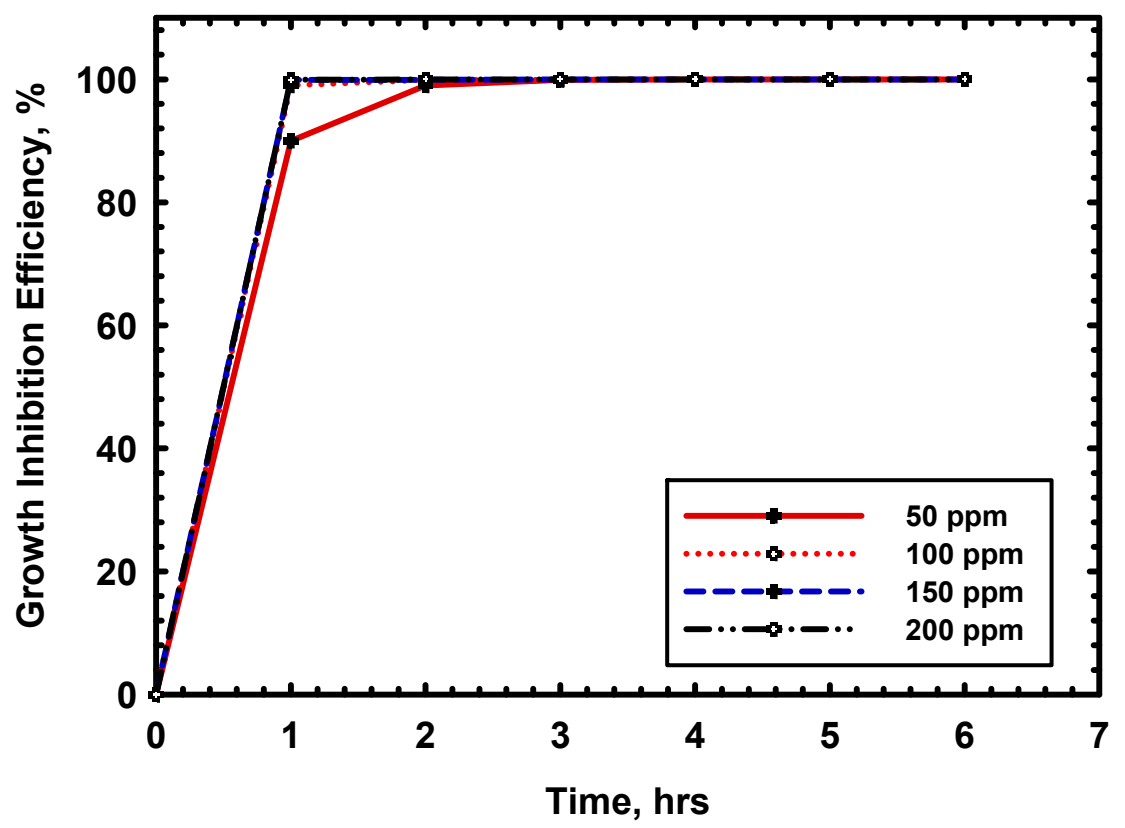

Figure 5. The inhibition efficiency of the bacterial growth in presence of different concentrations of [EMIm]Cl.

\subsection{Anticorrosion Effect of the Employed Ionic Liquids}

In order to investigate the anti-corrosion impact of the employed ionic liquids, potentiodynamic polarization experiments were carried out. Figure 6 shows the potentiodynamic polarization curves of mild steel electrodes in $3.5 \% \mathrm{NaCl}$ solutions with and without different concentrations of [OH-EMIm]Cl. It is clearly seen that both anodic and cathodic branches of the polarization curves wereinfluenced in the presence of the employed ionic liquid. The current densities shifted to lower values and the corrosion current significantly decreased, and also the corrosion potential shifted to the anodic direction. At a concentration of $10 \mathrm{ppm}$, the shift in the corrosion potential increased and the corrosion current exhibited a further decrease. This signifies the corrosion inhibition influence of the ionic liquid [OH-EMIm] Cl. Increasing the ionic liquid concentration above $10 \mathrm{ppm}$ didnot lead to a significant change in the polarization curves (the curves are not shown). The inhibiting effect couldbe attributable to the adsorption of the ionic liquid species, cations, onthe surface of mild steel forming a protective layer against the corrosion attack. Once the protective layer of the adsorbed ionic liquid is formed, a further increase in the ionic liquid content would not lead to a subsequent increase in the inhibiting influence.

The potentiodynamic polarization curves of mild steel in $3.5 \% \mathrm{NaCl}$ solutions without and with two different concentrations (5 and $10 \mathrm{ppm}$ ) of the ionic liquid [EMIm]Cl are shown in Figure 7. As in the case of [OH-EMIm]Cl, the addition of [EMIm] $\mathrm{Cl}$ to the employed electrolyte led to a significant inhibiting effect of the corrosion of mild steel as the corrosion current decreased. No further improvement in the inhibiting influence of [EMIm] $\mathrm{Cl}$ upon increasing the concentration above $10 \mathrm{ppm}$ occurred. It is obvious that the corrosion inhibition influence of the ionic liquid [OH-EMIm]Clwas higher than that of the ionic liquid [EMIm] Cl. This indicates the synergistic inhibition effect due to the incorporation of the hydroxyl group into the side chain of the imidazolium cation.The presence of the hydroxyl group in the imidazolium cation enhanced the adsorption capability of the cation of the employed ionic liquid due to the existence of two heteroatoms, $\mathrm{O}$ and $\mathrm{N}$. 


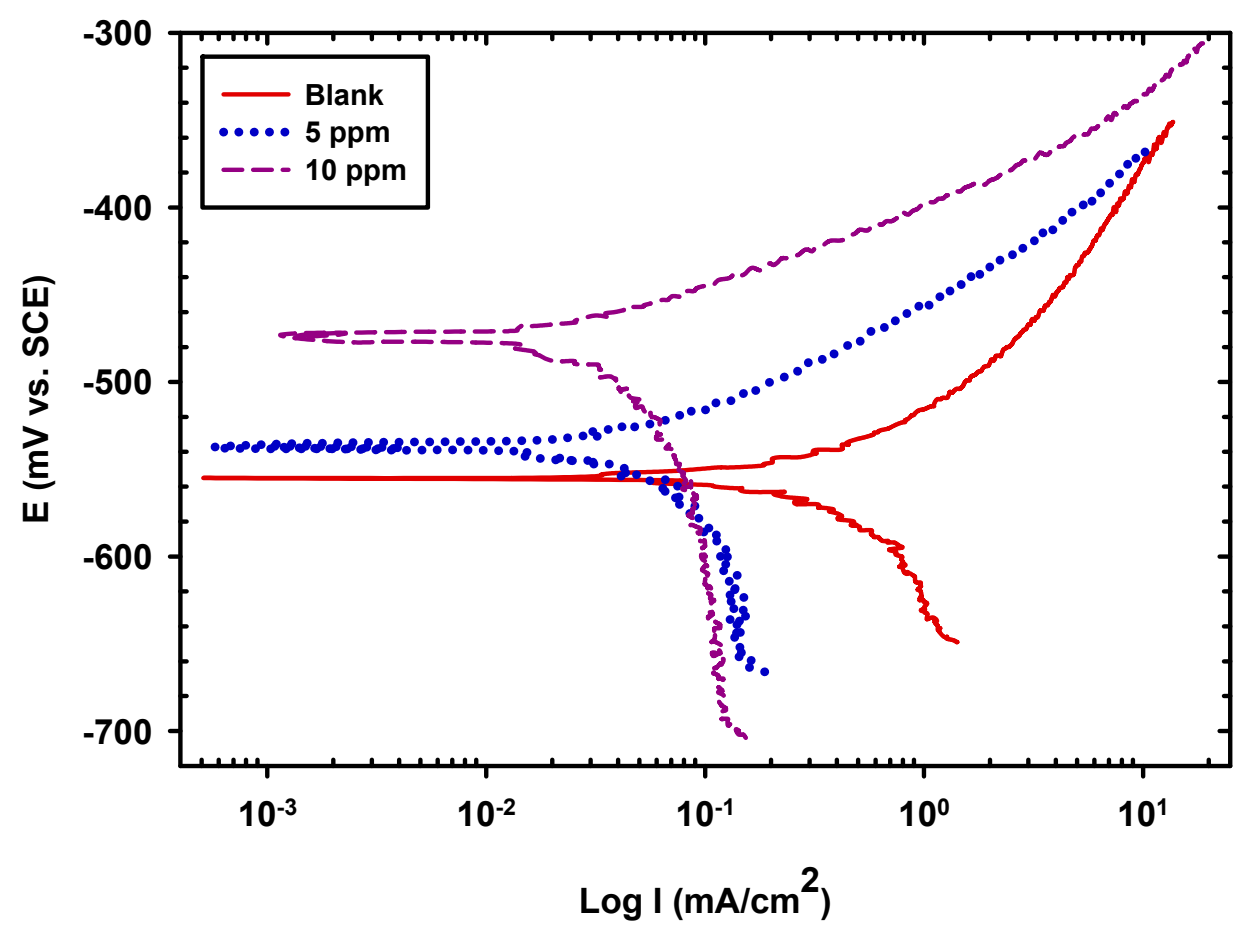

Figure 6. Potentiodynamic polarization curves for mild steel in $3.5 \% \mathrm{NaCl}$ solutions without and with different concentrations of [OH-EMIm]Cl.

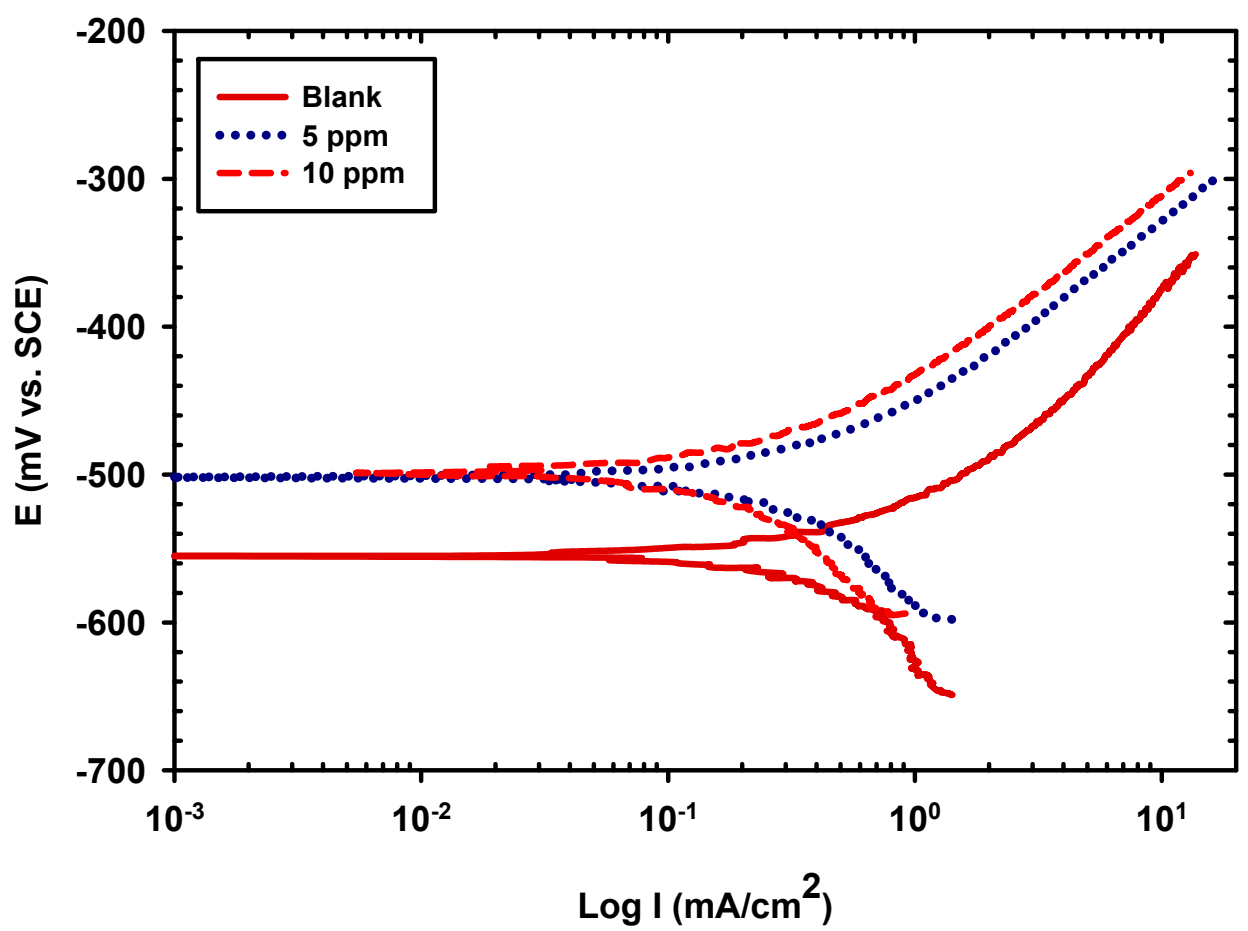

Figure 7. Potentiodynamic polarization curves for mild steel in $3.5 \% \mathrm{NaCl}$ solutions without and with different concentrations of [EMIm]Cl.

\section{Conclusions}

The effect of the ionic liquids [OH-EMIm] $\mathrm{Cl}$ and [EMIm] $\mathrm{Cl}$ on the inhibition of the planktonic bacterial growth and on the inhibition of mild steel corrosion in $3.5 \% \mathrm{NaCl}$ solutions was investigated. The results showed that the employed ionic liquids coulddually function as efficient biocides and 
also as acceptable corrosion inhibitors. Incorporation of the hydroxyl group into the side chain of the imidazolium cation leads to enhancing the antibacterial and anticorrosion influence of the ionic liquid. Compared with the ionic liquid [EMIm] $\mathrm{Cl}$, the ionic liquid [OH-EMIm] $\mathrm{Cl}$ showed a better biocidal influence and an enhanced corrosion inhibition effect.

Author Contributions: M.F.S. conducted most of the experimental work and prepared the first draft of the manuscript. A.M.E.-S. conducted the antibacterial experiments and participated in the preparation of the manuscript. K.M.Z. conducted the corrosion experiments. E.-S.M.S. conducted the corrosion experiments and participated in editing the manuscript. S.Z.E.A. evaluated the results and edited the final version of the manuscript. All authors have read and agreed to the published version of the manuscript.

Funding: The corrosion part of this study was conducted with the support of King Saud University, Riyadh, Saudi Arabia. The financial support by King Saud University through the project number RSP-2019/33 is acknowledged.

Conflicts of Interest: The authors declare no conflict of interest.

\section{References}

1. Aquaprox. Treatment of Cooling Water; Springer: Berlin, Germany, 2009.

2. Lewis, K. Riddle of biofilm resistance. Antimicrob Agents Chemother. 2001, 45, 999-1007. [CrossRef]

3. Rajasekar, A.; Ting, Y.P. Role of inorganic and organic medium in the corrosion behavior of Bacillus megaterium and Pseudomonas sp. in stainless steel SS 304. Ind. Eng. Chem. Res. 2011, 50, 12534-12541. [CrossRef]

4. Liu, Y.; Yang, C.H.; Li, J. Influence of extracellular polymeric substances on Pseudomonas aeruginosa transport and deposition profiles in porous media. Environ. Sci. Technol. 2007, 41, 198. [CrossRef] [PubMed]

5. Swaroop, B.S.; Victoria, S.N.; Manivannan, R. Azadirachtaindica leaves extract as inhibitor for microbial corrosion of copper by Arthrobactersulfureus in neutral $\mathrm{pH}$ conditionsa remedy to blue green water problem. J. Tai. Inst. Chem. Eng. 2016, 64, 269-278. [CrossRef]

6. Lutey, R.W. A review and comparison of MIC indices (Models). In Proceedings of the 62nd International Water Conference, Pittsburgh, PA, USA, 21-25 October 2011; p. 4.

7. El-Shamy, A.M.; Soror, T.Y.; El-Dahan, H.A.; Ghazy, E.A.; Eweas, A.F. Microbial corrosion inhibition of mild steel in salty water environment. Mater. Chem. Phys. 2009, 114, 156-159. [CrossRef]

8. Amin, M.A.; Ibrahim, M.M. Corrosion and corrosion control of mild steel in concentrated $\mathrm{H}_{2} \mathrm{SO}_{4}$ solutions by a newly synthesized glycine derivative. Corros. Sci. 2011, 53, 873-885. [CrossRef]

9. Javaherdashti, R. Microbiologically Influenced Corrosion an Engineering Insight; Springer: London, Germany, 2008.

10. Little, B.J.; Lee, J.S. Microbiologically Influenced Corrosion; Wiley: Hoboken, NJ, USA, 2007.

11. Guiamet, P.S.; Gomez de Saravia, S.G. Laboratory studies of biocorrosion control using traditional and environmentally friendly biocides: An overview. Latin Am. Appl. Res. 2005, 35, 295-300.

12. Narenkumar, J.; Parthipan, P.; Raja, A.U.; Benelli, G.; Murugan, K.; Rajasekar, A. Ginger extract as green biocide to control microbial corrosion of mild steel. Biotech 2017, 7, 133. [CrossRef] [PubMed]

13. Radojcic, I.; Berkovic, K.; Kovac, S.; Vorkapic-Furac, J. Natural honey and black radish juice as tin corrosion inhibitors. Corros. Sci. 2008, 50, 1498-1504. [CrossRef]

14. Ansari, K.R.; Quraishi, M.A. Experimental and quantum chemical evaluation of Schiff bases of isatin as a new and green corrosion inhibitors for mild steel in $20 \% \mathrm{H}_{2} \mathrm{SO}_{4}$. J. Tai. Inst. Chem. Eng. 2015, 54, 145-154. [CrossRef]

15. Lin, J.; Ballim, R. Biocorrosion control: Current strategies and promising alternatives. Afr. J. Biotechnol. 2012, 11, 15736-15747. [CrossRef]

16. Garg, N.; Aeron, A. Microbes in Process, Control of Corrosion Caused by Sulfate-Reducing Bacteria; Nova Science Publishers, INC.: Hauppauge, NY, USA, 2014; Chapter 14; pp. 337-362.

17. El-Shamy, A.M.; Zakaria, K.; Abbas, M.A.; El Abedin, S.Z. Anti-bacterial and anti-corrosion effects of the ionic liquid1-butyl-1-methylpyrrolidinium trifluoromethylsulfonate. J. Mol. Liq. 2015, 211, 363-369. [CrossRef]

18. Carson, L.; Chau, P.K.W.; Earle, M.J.; Gilea, M.A.; Gilmore, B.F.; Gorman, S.P.; McCann, M.T.; Seddon, K.R. Antibiofilm activities of 1-alkyl-3-methylimidazolium chloride ionic liquids. Green Chem. 2009, 11, 492-497. [CrossRef] 
19. Bica, K.; Cooke, L.R.; Nugent, P.; Rijksen, C.; Rogers, R.D. Toxic on purpose: Ionic liquid fungicides as combinational crop protecting agents. Green Chem. 2011, 13, 2344-2346. [CrossRef]

20. Hossain, M.I.; El-Harbawi, M.; Alitheen, N.B.M.; Noaman, Y.A.; Leveque, J.M.; Yin, C.Y. Synthesis and anti-microbial potencies of 1-(2-hydroxyethyl)-3-alkylimidazoliumchloride ionic liquids: Microbial viabilities at different ionic liquids concentrations. Ecotoxicol. Environ. Saf. 2013, 87, 65-69. [CrossRef] [PubMed]

21. Sung, E.H.; Han, J.S.; Ahn, C.M.; Seo, H.J.; Kim, C.G. Biological metal corrosion in saline systems by sulfur-reducing and iron-oxidizing bacteria, Water Qual. Res. J. Can. 2011, 46, 321-331.

22. Starosvetsky, J.; Starosvetsky, D.; Pokroy, B.; Hilel, T.; Armon, R. Electrochemical behaviour of stainless steels in media containing iron-oxidizing bacteria (IOB) by corrosion process modeling. Corros. Sci. 2008, 50, 540-547. [CrossRef]

23. Rao, T.S.; Sairam, T.N.; Viswanathan, B.; Nair, K.V.K. Carbon steel corrosion by iron oxidising and sulphate reducing bacteria in a freshwater cooling system. Corros. Sci. 2000, 42, 1417-1431.

24. Liu, H.; Fu, C.; Gu, T.; Zhang, G.; Lv, Y.; Wang, H.; Liu, H. Corrosion behavior of carbon steel in the presence of sulfate reducing bacteria and iron oxidizing bacteria cultured in oilfield produced water. Corros. Sci. 2015, 100, 484-495. [CrossRef]

25. Wakai, S.; Ito, K.; Iino, T.; Tomoe, Y.; Mori, K.; Harayama, S. Corrosion of iron by iodide-oxidizing bacteria isolated from brine in an iodine production facility. Microb. Ecol. 2014, 68, 519-527. [CrossRef]

26. Ibsen, N.B.; Ma, H.; Banerjee, A.; Tanner, S.; Nangia, E.E.; Mitragotri, S. Mechanism of Antibacterial Activity of Choline-Based Ionic Liquids (CAGE). ACS Biomater. Sci. Eng. 2018, 4, 2370-2379. [CrossRef]

27. Lewandowski, Z.; Beyenal, H. Mechanisms of microbially influenced corrosion. In Marine and Industrial Biofouling; Flemming., H.C., Murthy, P.S., Venkatesan, R., Cooksey, K., Eds.; Springer: Berlin, Germany, 2009; pp. 35-64.

(C) 2020 by the authors. Licensee MDPI, Basel, Switzerland. This article is an open access article distributed under the terms and conditions of the Creative Commons Attribution (CC BY) license (http://creativecommons.org/licenses/by/4.0/). 